\title{
Wybrane aspekty współpracy samorządu terytorialnego z organizacjami pozarządowymi w realizacji zadań publicznych*
}

\section{Selected Aspects of the Cooperation of Territorial Self-government with Non-governmental Organizations in the Realization of Public Tasks*}

Streszczenie. Organizacje pozarządowe współpracują z samorządem terytorialnym ze względu na wspólne cele oraz środki publiczne będące w gestii władz terytorialnych. Władze te powinny w większym stopniu delegować zadania pu-

* Niniejszy tekst stanowi zmodyfikowaną wersję referatu przygotowanego na Ósmą Międzynarodową Konferencję Naukową pt. „Social Sciences for Regional Development 2013”, zorganizowaną w dniach 10-12 października 2013 r. przez Uniwersytet w Daugavpils (Łotwa). / The given text is a modified version of a paper prepared for the 8th International Scientific Conference „Social Sciences for Regional Development 2013”, organized in the period 10th-12th of October, 2013 by Daugavpils University (Latvia). 
bliczne do tych organizacji, gdyż pozwoliłoby to na uzupełnienie luki w zaspokojeniu potrzeb mieszkańców oraz rozwiązywać różnorakie problemy społeczne we wspólnotach terytorialnych. Tekst prezentuje wybrane aspekty współpracy pomiędzy organizacjami pozarządowymi w Polsce a samorządem terytorialnym, szczególnie województwami. Na początku przedstawiono miejsce i rolę organizacji pozarządowych w gospodarce i społeczeństwie. Następna część dotyczy płaszczyzn współpracy jednostek samorządowych z tymi organizacjami w Polsce. Analiza współpracy pomiędzy wymienionymi partnerami w gospodarce regionalnej w aspekcie finansowym została dokonana na przykładzie samorządu województwa kujawsko-pomorskiego.

Słowa kluczowe: organizacje pozarządowe; współpraca z samorządem terytorialnym; zadania publiczne.

\begin{abstract}
The NGOs cooperate with self-government because they have common goals, as well as because of the public funds that are at the disposal of territorial authorities. Public authorities should to higher extend delegate the public tasks to NGOs as those organizations, undertaking a part of public tasks devoted to self-governments, fill in the gaps in meeting the inhabitants' needs, as well as solve numerous social problems in territorial units. The article presents the selected aspects of cooperation between NGOs in Poland and public authorities operation on a regional level. Firstly, the place and role of NGOs in the economy and society was presented. The next part concerns areas of cooperation of self-government units with NGOs in Poland. The analysis of financial cooperation between the given partners was presented on an example of the regional situation of the Kuyavian-Pomeranian Voivodeship Self-government.
\end{abstract}

Keywords: non-governmental organizations; cooperation with self-government; public tasks.

\title{
1. Wstęp
}

Organizacje pozarządowe (ang. non-governmental organizations, NGO) należą do szerokiej grupy podmiotów funkcjonujących na rynku, których działanie nie jest ukierunkowane na zysk, ale jedynie na wypełnienie luki w dostarczaniu ludności dóbr i usług w tych sferach, które nie są wykonywane przez sektor publiczny lub są wykonywane w sposób niewystar- 
czający. Organizacje te z założenia są niezależne od administracji publicznej zarówno rządowej, jak i samorządowej. Odgrywają coraz istotniejszą rolę we współczesnym świecie, co przejawia się w ich wzroście ilościowym oraz zwiększonym wpływie na kształt różnorakiej aktywności społeczeństwa. Unia Europejska wspiera działania NGO, ponieważ zwiększają one swoją aktywnością spójność społeczną, a w dalszej perspektywie również spójność ekonomiczną społeczeństwa.

W Polsce po 1989 r. zanotowano duży przyrost liczby organizacji pozarządowych, zwłaszcza w pierwszych latach transformacji ustrojowej. Rozwój tzw. trzeciego sektora spowodowany był zmieniającą się rolą sektora publicznego, którego zakres aktywności został wyraźnie ograniczony. Sektor organizacji pozarządowych zmobilizował wtedy społeczeństwo do organizacji i finansowania działalności usługowej, którą do tej pory zajmowało się państwo.

W ostatnich latach w związku z przeżywanym kryzysem finansowym, w tym w sektorze finansów publicznych, wzrastać zaczęła rola organizacji pozarządowych. Samorządy stanęły przed koniecznością racjonalizacji wydatków bieżących. Zlecanie zadań NGO stało się dla nich swoistą metodą racjonalizacji części wydatków budżetowych. W wyniku delegowania zadań mogą one być realizowane w sposób bardziej efektywny i oszczędny. Dobro mieszkańców wymusza zatem konieczność współpracy jednostek samorządowych z organizacjami pozarządowymi, umożliwiającej łączenie publicznych i niepublicznych środków finansowych, w celu realizowania zadań publicznych. Co ważne, organizacje te muszą posiadać tzw. wkład własny, wszystko to natomiast sprzyja postępującej profesjonalizacji organizacji pozarządowych.

Chociaż w literaturze polskiej istnieje duża liczba artykułów i książek poświęconych rozwojowi i funkcjonowaniu sektora organizacji pozarządowych, to temat ten jest daleki od wyczerpania i pozostaje w nim wiele luk wartych eksploracji. Celem niniejszego opracowania jest zaprezentowanie roli i miejsca organizacji pozarządowych w gospodarce lokalnej i regionalnej oraz ukazanie na tym tle możliwości współpracy samorządu terytorialnego z organizacjami pozarządowymi w dziedzinie dostarczania usług publicznych na rzecz mieszkańców. W opracowaniu przed- 
stawiono również analizę współdziałania samorządu województwa kujawsko-pomorskiego z organizacjami pozarządowymi w oparciu o przyjęty przez sejmik tego regionu wieloletni program współpracy w tej dziedzinie. Głównym celem opracowania jest przedstawienie potrzeby postrzegania sektorów: administracji publicznej - zwłaszcza na poziomie samorządowym - i organizacji pozarządowych nie jako konkurujących z sobą, ale uzupełniających się w rozwiązywaniu problemów społecznych oraz dostarczaniu dóbr i usług mieszkańcom.

\section{Miejsce i rola organizacji pozarządowych w gospodarce i społeczeństwie}

W systemie rynkowym spotykamy nierzadko sytuacje, w których realizacja przedsięwzięć, najczęściej o charakterze użyteczności publicznej, wymaga zaangażowania określonych środków w imię dobra wspólnego, stanowiącego wartość nadrzędną. Efekty uzyskiwane dzięki ich zaangażowaniu są jednak trudno mierzalne i uniemożliwiają porównywanie kosztów z dochodami. W rozwiniętych gospodarkach rynkowych w realizację tego typu przedsięwzięć coraz częściej angażują się organizacje pozarządowe. Występują one jako partner sektora prywatnego i publicznego w kształtowaniu rzeczywistości społeczno-gospodarczej. Urszula Grzelońska uważa, że czynnikiem wyjaśniającym istnienie takiej formy aktywności społecznej i gospodarczej jest niehomogeniczność ludzkich potrzeb, których nie można zaspokoić w społeczeństwie rozpatrywanym jako układ złożony z dwóch sektorów ${ }^{1}$. W literaturze światowej już od lat 70. XX w. używa się dość pojemnego określenia „trzeci sektor” (ang. third sector). Termin ten wskazuje na opozycję w stosunku do sektora zarówno publicznego (tzw. pierwszego), jak i prywatnego (tzw. drugiego). Chodziłoby tu o dobrowolnie zorganizowaną grupę obywateli, która działałaby w niekomercyjnym celu, podejmując się realizacji zadań publicznych dla dobra mieszkańców. Było to rozumiane jako alternatywa dla wad

U. Grzelońska, Rola sektora non profit w polskiej gospodarce, „Studia Ekonomiczne” 2011, nr 4 (LXXI), s. 342. 
maksymalizacji zysku oraz biurokracji administracji publicznej ${ }^{2}$. W polskiej literaturze najczęściej „trzeci sektor” traktuje się zamiennie z terminem „organizacje pozarządowe” lub „organizacje non profit”. Stwierdza się zatem, że „te trzy rodzaje organizacji są jedynie trzema rolami w jakich występuje w gospodarce i społeczeństwie jedna i ta sama organizacja”3.

W polskim prawie definicję ustawową organizacji pozarządowych zawiera ustawa z dnia 24 kwietnia 2003 r. o działalności pożytku publicznego i o wolontariacie ${ }^{4}$. Zgodnie $\mathrm{z}$ tą definicją organizacjami pozarządowymi są niebędące jednostkami sektora finansów publicznych i niedziałające w celu osiągnięcia zysku osoby prawne lub jednostki nieposiadające osobowości prawnej, ale posiadające zdolność prawną, w tym fundacje i stowarzyszenia. Organizacje pozarządowe mogą funkcjonować w Polsce w różnych formach organizacyjno-prawnych, np. jako stowarzyszenia zwykłe lub stowarzyszenia nierejestrowane, fundacje, osoby prawne i jednostki organizacyjne kościołów i związków wyznaniowych prawnie uznanych wyznań, spółdzielnie socjalne, kluby sportowe itp. Nie ma więc znaczenia forma organizacyjna, w jakiej obywatele realizują cele społecznie użyteczne ${ }^{5}$.

Działalność sektora organizacji pozarządowych oparta jest przede wszystkim na posiadanym kapitale ludzkim, który stanowi ich największy zasób. W Polsce na początku 2011 r. w rejestrze REGON Głównego Urzędu Statystycznego zarejestrowanych było ponad 130 tys. podmiotów zaliczanych do sektora pozarządowego. Trzon zarejestrowanych organizacji stanowiły stowarzyszenia (ok. 65 tys.) oraz fundacje (ok. 11 tys.). Należy jednak pamiętać, że liczba zarejestrowanych organizacji nie odzwierciedla liczby aktywnie działających podmiotów. Organizacje nie

\footnotetext{
2 W. Seibel, H.K. Anheier, Sociological and political science approaches to the third sector, [w:] H.K. Anheier, W. Seibel (red.), The Third Sector: Comparative Studies of Nonprofit Organisations, Berlin-New York, 1990, s. 7-8.

U. Grzelońska, Rola sektora..., s. 326.

Tekst jedn. Dz.U. z 2010 r., Nr 234, poz. 1536 ze zm.

Z. Ofiarski, Finansowanie zadań zleconych przez gminę organizacjom pozarzq̨dowym, „Annales Universitatis Mariae Curie-Skłodowska”, Sectio H Oeconomia, vol. XLVI, 3, Lublin 2012, s. 384.
} 
mają obowiązku wyrejestrowywania się z oficjalnych wykazów, w związku z tym okazuje się, że duża część tych, które zakończyły swoją działalność, nadal w nich figuruje. $Z$ badań społecznych realizowanych przez GUS wynika, że na początku 2011 r. aktywnie działało jedynie ok. 77 tys. podmiotów, czyli ok. $60 \%$ całej zbiorowości ${ }^{6}$. Badania te podkreślają pogłębiające się rozwarstwienie aktywności społecznej, związane z lokalizacją siedziby działalności organizacji. Największa ich liczba w przeliczeniu na liczbę mieszkańców znajduje się w województwie mazowieckim i pomorskim, a najmniejsza - w opolskim i świętokrzyskim. Co czwarta aktywna organizacja w Polsce ma siedzibę w mieście powyżej 500 tys. mieszkańców - tam też jest największe ich zagęszczenie, średnio 33 organizacje na 10 tys. mieszkańców. Na początek 2011 r. badany sektor według szacunków GUS-u zatrudniał ponad 103 tys. pracowników w ramach stosunku pracy, a jeśli weźmie się pod uwagę osoby, dla których organizacje nie były głównym miejscem pracy, to liczba ta wzrasta do 123 tys. osób. Zatrudnienie w tych podmiotach charakteryzuje się wyraźną feminizacją - aż 73\% zatrudnionych stanowiły kobiety.

Jeśli chodzi o główne pola aktywności organizacji pozarządowych, to w latach 90. XX w. głównymi obszarami tej działalności były edukacja i wychowanie oraz ochrona zdrowia i usługi socjalne, natomiast w latach późniejszych, szczególnie od 2004 r., zaczęły dominować sport i turystyka, edukacja i wychowanie oraz kultura i sztuka. Niektóre obszary pozostają więc kluczowymi dziedzinami aktywności sektora niezmiennie (edukacja i wychowanie), a część z nich staje się z czasem częściej (sport i turystyka, kultura i sztuka) lub rzadziej (ochrona zdrowia) reprezentowana. Zmiany te mają związek z przemianami społeczno-gospodarczymi w kraju i ogólnym wzrostem zamożności społeczeństwa ${ }^{7}$.

Finansowanie podejmowanych działań od wielu lat uznawane jest za podstawowy problem organizacji pozarządowych. Trudność ta związana jest przede wszystkim z brakiem środków pieniężnych, z czym perma-

6 Wybrane statystyki dotyczące funkcjonowania organizacji pozarządowych w Polsce, www.civicpedia.ngo.pl.

7 U. Grzelońska, Rola sektora..., s. 329-330 oraz J. Schmidt, Rozwój organizacji pozarzq̨dowych. Teoria i praktyka, Warszawa 2012, s. 76-77. 
nentnie borykają się organizacje. Obecnie podmioty organizacji pozarządowych pozyskują fundusze na swoją statutową działalność głównie z trzech typów źródeł:

- $\quad$ wpływy z różnego rodzaju opłat (składki członkowskie, płatne usługi),

- $\quad$ dochody pochodzące z sektora prywatnego (filantropijne) - środki od prywatnych osób lub firm, zbiórki publiczne itp.,

- $\quad$ wpływy płynące z instytucji publicznych (dotacje ze źródeł samorządowych i rządowych, a także wpływy z przekazanego $1 \%$ podatku ${ }^{8}$ oraz dotacje z zagranicznych źródeł publicznych).

Z wymienionych źródeł umożliwiających uzyskanie dochodu organizacje korzystają w różnym stopniu. Najpopularniejszym sposobem pozyskiwania funduszy na działalność były i nadal pozostają składki członkowskie. Źródłami, z których organizacje korzystają obecnie zdecydowanie częściej niż np. 15 lat temu, są przede wszystkim środki pochodzące z dotacji jednostek samorządu terytorialnego (w 1997 r. było to ok. 15\%, a w 2012 r. - ponad 52\%). Wskazuje to na zacieśnianie i polepszanie relacji sektora organizacji pozarządowych z przedstawicielami władz samorządowych. Coraz rzadziej natomiast organizacje korzystają ze środków budżetu państwa ${ }^{9}$.

Samorządowy sektor publiczny, odpowiedzialny za wytwarzanie dóbr publicznych, z powodu nasilających się problemów finansowych intensyfikuje współpracę z organizacjami pozarządowymi, które przejmują część opisanych powyżej zadań. Zakres działań tych organizacji jest wyznaczany nie tyle w oparciu o kryterium ekonomiczne, co ze względu na realizację wartości nadrzędnych, takich jak więź społeczna czy poczucie bezpieczeństwa socjalnego. Najbardziej popularne dziedziny to: sport, turystyka i hobby, a także edukacja, wychowanie i kultura. Stąd wynika, że trzeci sektor jest ważną częścią życia publicznego i przyczynia się do tworzenia tkanki społeczeństwa obywatelskiego. Główną zaletą organizacji pozarządowych jest też duża swoboda w wyborze metod działania, elastyczność i efektywność w zaspokajaniu potrzeb społecznych. Poza

Dotyczy to tylko organizacji pożytku publicznego.

J. Schmidt, Rozwój organizacji..., s. 78-81. 
tym dysponują one wiedzą dużym zasobem informacji o lokalnych potrzebach i problemach wynikającą z ich codziennych kontaktów, przez co często aktywizują obywateli i pomagają im bardziej skutecznie aniżeli samorządy terytorialne.

\section{Płaszczyzny współdziałania jednostek samorządu terytorialnego z organizacjami pozarządowymi}

Samorząd terytorialny został powołany jako podmiot uczestniczący w sprawowaniu władzy publicznej. W ten sposób wykonuje on znaczną część zadań publicznych. Zatem organy samorządu terytorialnego są podmiotami publicznymi wykonującymi część zadań administracji publicznej. Jednostki samorządu terytorialnego w Polsce są odpowiedzialne za wykonywanie zadań własnych i zleconych. Zadania własne samorząd realizuje we własnym zakresie, biorąc za nie pełną odpowiedzialność. Odpowiednie ustawy regulują, które z zadań własnych mają charakter obowiązkowy, a które fakultatywny. Podział zadań na własne i zlecone jest uzależniony od przyjętej przez państwo $\mathrm{w}$ danym okresie polityki społecznej i gospodarczej. Poszczególne rodzaje zadań wraz z ewolucją warunków, planów i koncepcji również ulegają licznym zmianom. Omawiane zadania to $\mathrm{z}$ jednej strony różnego rodzaju usługi świadczone na rzecz społeczności lokalnych, ale z drugiej także przedsięwzięcia rozwojowe, podejmowane dla zwiększenia bazy dochodowej oraz możliwości świadczenia usług w przyszłości. Wpływają one w znaczący sposób na jakość życia mieszkańców danej jednostki terytorialnej oraz determinują rozwój całego regionu w długim okresie. Ważne zatem jest, by jak największa część tych usług była realizowana przy zaangażowaniu odpowiednich zasobów. Taką możliwość daje partnerstwo z organizacjami pozarządowymi, które sprzyja m.in. łączeniu zasobów wiedzy o potrzebach i problemach środowiska lokalnego.

Zgodnie z obowiązującymi przepisami prawnymi istnieje szeroko rozbudowany katalog możliwości współpracy z rożnymi podmiotami niepublicznymi na rzecz realizacji zadań. Są to m.in.: umowy o zamówienia publiczne, umowy o partnerstwie publiczno-prywatnym oraz powie- 
rzanie zadań organizacjom pozarządowym. Szczególne znaczenie zyskała w ostatnich kilkunastu latach zwłaszcza ta ostatnia forma współpracy.

Współpraca między samorządem a organizacjami pozarządowymi zgodnie z treścią ustawy o działalności pożytku publicznego może odbywać się w następujących formach ${ }^{10}$ :

- $\quad$ zlecania organizacjom pozarządowym realizacji zadań publicznych;

- $\quad$ wzajemnego informowania się o planowanych kierunkach działalności;

- $\quad$ konsultowania z organizacjami pozarządowymi projektów aktów normatywnych w dziedzinach dotyczących ich statutowej działalności;

- $\quad$ konsultowania projektów aktów normatywnych dotyczących sfery zadań publicznych z Radami Działalności Pożytku Publicznego w przypadku ich utworzenia przez właściwe jednostki samorządu terytorialnego;

- $\quad$ tworzenia wspólnych zespołów o charakterze doradczym i inicjatywnym, złożonych z przedstawicieli organizacji pozarządowych i właściwych organów administracji publicznej;

- $\quad$ umowy o wykonanie inicjatywy lokalnej;

- $\quad$ umów partnerstwa.

Mechanizm kooperacji pomiędzy samorządem a trzecim sektorem opiera się na tzw. programach współpracy ${ }^{11}$. Konieczność ich uchwalania przez organ stanowiący samorządu wprowadziła ustawa z dnia 22 stycznia 2010 r. o zmianie ustawy o działalności pożytku publicznego i o wolontariacie oraz niektórych innych ustaw ${ }^{12}$. Według ustawy każdy samorząd zobowiązany jest do uchwalenia rocznego programu współpracy z organizacjami pozarządowymi do 30 listopada roku poprzedzającego.

10 Art. 5 Ustawy o działalności pożytku publicznego i wolontariacie.

11 Zob.: I. Czaja-Hliniak, Prawnofinansowe aspekty współpracy jednostek samorzq̨du terytorialnego $\mathrm{z}$ organizacjami pozarzqdowymi $w$ realizacji zadań publicznych na przykładzie gminy - miasta metropolitalnego, [w:] J. Gliniecka, E. Juchniewicz, T. Sowiński, M. Wróblewska (red.), Prawo finansowe samorzq̨du terytorialnego. Prawo finansowe wobec wyzwań XXI wieku, Gdańsk-Nynäshamn-Sztokholm 2013, s. 90-91.

12 Art. 5a ustawy o działalności pożytku publicznego i wolontariacie. 
Przy sporządzaniu programu współpracy samorządy konsultują zagadnienia $\mathrm{w}$ nich zawarte $\mathrm{z}$ organizacjami pozarządowymi. Treść programu obejmuje m.in. okres i sposób realizacji zadań publicznych, sposób przeprowadzenia konkursu ofert oraz wysokość środków przeznaczanych na realizacje programu. Fakultatywnie organ stanowiący samorządu może uchwalić także wieloletni program współpracy.

Współpraca między organizacjami pozarządowymi a jednostkami samorządowymi może zostać zinstytucjonalizowana poprzez utworzenie tzw. Rady Działalności Pożytku Publicznego (RDPP). Rada ta może fakultatywnie być powołana przez zarząd samorządu na wniosek organizacji pozarządowych działających na określonym terenie. Stanowi ona wówczas organ konsultacyjny i opiniodawczy. Kadencja RDPP wynosi dwa lata.

Efektywność realizowanej współpracy zależy od poszanowania podstawowych zasad przez wszystkich partnerów. Do zasad tych należą:

- zasada pomocniczości - samorząd i organizacje pozarządowe uzupełniają nawzajem zakres swojej wiedzy i kompetencji; samorządy w realizacji swojej polityki rozwoju powinny korzystać z potencjału organizacyjnego, osobowego i technicznego trzeciego sektora; tylko wówczas możliwe jest pełne zdiagnozowanie lokalnych problemów i potrzeb;

- $\quad$ zasada suwerenności stron - zarówno samorządy, jak i organizacje pozarządowe oczekują poszanowania swojej autonomii;

- $\quad$ zasada partnerstwa - organizacje trzeciego sektora są pełnoprawnym i równym partnerem dla samorządu w identyfikowaniu i rozwiązywaniu problemów społecznych;

- $\quad$ zasada efektywności - samorząd, zlecając zadania publiczne, kieruje się wyborem najbardziej efektywnego sposobu ich realizacji spośród zaproponowanych przez organizacje pozarządowe, oczekując od nich gospodarnego wydatkowania środków publicznych, rzetelnej realizacji powierzonych zadań oraz wywiązywania się z obowiązków sprawozdawczych;

- $\quad$ zasada uczciwej konkurencji - samorząd jest bezinteresowny i bezstronny w stosunku do organizacji pozarządowych; w przypadku 
ogłaszania otwartych konkursów ofert, wobec wszystkich podmiotów konkurujących ze sobą o realizację zadań publicznych, stosuje się te same kryteria oceny;

- zasada jawności - samorząd udostępnia zainteresowanym podmiotom informacje o planach, celach i środkach przeznaczonych na realizację zadań publicznych; dąży do tego, aby wszelkie aspekty współpracy z organizacjami pozarządowymi były zrozumiałe i powszechnie dostępne; od organizacji oczekuje się jawności w działalności statutowej, poprzez zamieszczanie stosownych informacji na stronach internetowych organizacji.

Powierzanie zadań publicznych do realizacji przez organizacji pozarządowe odbywa się w drodze tzw. otwartego konkursu ofert. Jest on organizowany z inicjatywy samorządu lub na wniosek organizacji pozarządowej. Omawiany tryb nie jest wymagany dla zlecenia zadań w przypadkach wystąpienia klęski żywiołowej, katastrofy naturalnej lub awarii technicznej $^{13}$. Informacja o konkursie powinna zawierać następujące dane: typ zadania i wysokość finansowania, warunki realizacji zadania publicznego, terminy i zasady realizacji, termin składana ofert, kryteria wyboru. Ustawa o działalności pożytku publicznego zawiera katalog kryteriów oceny stosowanych w otwartych konkursach ofert. Są nimi m.in.: możliwość realizacji zadania publicznego przez organizację pozarządową, przedstawiona kalkulacja kosztów, proponowana jakość wykonania zadania oraz kwalifikacje osób zaangażowanych w jego realizację, jeżeli jest to niezbędne - planowany przez organizację pozarządową udział środków własnych lub pochodzących z innych źródeł, planowany wkład rzeczowy i osobowy, rzetelność i terminowość wykonania zadań oraz sposób rozliczenia środków w przypadku realizacji zadań w poprzednich latach. Wybrane $\mathrm{w}$ konkursie organizacje pozarządowe podpisują $\mathrm{z}$ samorządem stosowną umowę określającą wszelkie zasady realizacji powierzonych zadań. Dotyczą one m.in.: przedmiotu umowy, finansowania, sposobu

13 M. Ofiarska, Zasady zlecania organizacjom pozarzqdowym wykonania zadań gminy, „Annales Universitatis Mariae Curie-Skłodowska”, Sectio H Oeconomia, vol. XLVI, 3, Lublin 2012, s. 377. 
rozliczenia, uprawnień i obowiązków w zakresie kontroli i sprawozdawczości $^{14}$.

\section{Analiza współpracy finansowej samorządu województwa kujawsko-pomorskiego z organizacjami pozarządowymi}

W związku ze wzrastającym zadłużeniem jednostek samorządu terytorialnego oraz wprowadzeniem nowych zasad równoważenia budżetów władze samorządowe zostały zmuszone do racjonalizacji wydatków bieżących. Jednym z rozwiązań służących obniżeniu wydatków bieżących samorządu jest przekazywanie realizacji określonego zadania podmiotowi organizacji pozarządowej i wsparcie go odpowiednimi środkami finansowymi. Od początku swego istnienia samorząd województwa kujawsko-pomorskiego dostrzegał potrzebę wspierania aktywności obywatelskiej, która ma znaczący wpływ na rozwój regionu we wszystkich sferach życia społecznego. Już od 2000 r. organizowane są doroczne Wojewódzkie Fora Organizacji Pozarządowych, a od 2003 r. działa Rada Organizacji Pozarządowych Województwa Kujawsko-Pomorskiego stanowiąca reprezentację organizacji działających $\mathrm{w}$ regionie ${ }^{15}$. Od wejścia w życie ustawy o działalności pożytku publicznego co roku wspieranych jest finansowo kilkaset projektów realizowanych przez podmioty trzeciego sektora.

Po przeprowadzeniu szerokich konsultacji społecznych z organizacjami samorządowymi po raz pierwszy uchwalony został Wieloletni Program Współpracy (WPW) samorządu województwa z organizacjami pozarządowymi na lata 2011-2015 ${ }^{16}$. WPW z organizacjami pozarządowymi jest najważniejszym dokumentem regulującym współpracę sektora pozarządowego z samorządem województwa. Program wieloletni podda-

14 Więcej o zasadach współpracy i modelu współpracy administracji publicznej i organizacji pozarządowych na stronie internetowej www.pokl541.pozytek.gov.pl.

15 Wraz z uchwaleniem w dniu 10 czerwca 2011 r. nowego regulaminu Rada zmieniła nazwę na Sejmik Organizacji Pozarządowych Województwa Kujawsko-Pomorskiego.

16 Załącznik do uchwały nr XV/267/11 sejmiku województwa kujawsko-pomorskiego $\mathrm{z}$ dnia 28 listopada $2011 \mathrm{r}$. 
ny został konsultacjom społecznym, w których aktywnie wzięły udział stowarzyszenia i fundacje z regionu województwa. Dokument zawiera cel główny oraz precyzuje pięć celów szczegółowych. Głównym celem programu jest rozwój społeczeństwa obywatelskiego oraz zwiększenie stopnia zaspokojenia potrzeb społecznych. Cel ten będzie osiągnięty poprzez realizację następujących zadań szczegółowych:

- $\quad$ aktywizowanie społeczności lokalnych z zapewnieniem równości szans rozwoju;

- budowanie partnerskiej współpracy opartej o wzajemne zaufanie stron;

- $\quad$ bieżące rozpoznawanie potrzeb społecznych i potencjału organizacji pozarządowych;

- $\quad$ zwiększenie efektywności realizacji zadań publicznych;

- $\quad$ wspieranie współpracy organizacji pozarządowych w wymiarze terytorialnym i branżowym.

Łączna planowana kwota przeznaczona na realizację WPW wynosi ponad 27 mln zł. Na każdy rok od 2011 do 2015 przypadać będzie ok. 5,3 mln zł na współpracę z organizacjami pozarządowymi. Program wieloletni jest tworzony przez samorząd fakultatywnie. W województwie kujawsko-pomorskim podjęto decyzję o utworzeniu takiego planu. W ten sposób powstają podstawy przedmiotowe i finansowe programów rocznych, które według przepisów prawnych są już obligatoryjne. Zwiększa to przejrzystość działań samorządu oraz ułatwia planowanie rocznych programów.

Z dotychczas zrealizowanych programów z planu wieloletniego (w latach 2011-2012) najwięcej środków finansowych pochłonęły zadania związane z kulturą fizyczną i sportem, oraz kultura, sztuką i dziedzictwem narodowym (Tabela 1.). Na ogół organizacje zajmujące się sportem, turystyką i rekreacją nie zatrudniają pracowników w formie umowy o pracę, a prace na rzecz organizacji wykonują w dużej mierze jej członkowie przy wsparciu wolontariatu. Współpraca organizacji z wolontariatem nie jest sformalizowana. Organizacje zajmujące się sportem skupiają się głównie na promocji aktywności fizycznej wśród osób niepełnosprawnych i pełnosprawnych. Zadaniem organizacji zrzeszających osoby nie- 
pełnosprawne jest promocja sportu jako skutecznego środka rehabilitacji ruchowej i umysłowej oraz wspieranie akceptacji osób niepełnosprawnych w ich otoczeniu społecznym. Z kolei organizacje sportowe, których beneficjentami są osoby pełnosprawne, najczęściej promują sport wśród osób, których sytuacja materialna nie pozwala na uczestniczenie w zajęciach sportowych w innych ośrodkach. NGO organizują zajęcia, opłacają wyjazdy turniejowe oraz zaopatrują uczestników w niezbędne wyposażenie, np. strój sportowy. Natomiast działania organizacji na rzecz turystyki ukierunkowane są na ogólną promocję, bez wskazania konkretnych obszarów i grup odbiorców.

Oferta organizacji pozarządowych zajmujących się kulturą i sztuką oraz dziedzictwem narodowym jest dość szeroka. Wachlarz inicjatyw podejmowanych przez organizacje z tego obszaru obejmuje m.in. zajęcia edukacyjne dla dzieci i młodzieży, prowadzenie warsztatów artystycznych, naukę gry na instrumentach muzycznych, czy też organizowanie obozów adaptacyjnych dla studentów, wypraw górskich, a także organizowanie wystaw i galerii, koncertów, promowanie współczesnej sztuki i wiele innych działań. Wspólnym mianownikiem organizacji samorządowych z zakresu kultury i sztuki jest wielka pasja i wrażliwość jej liderów na malejące zainteresowanie kulturą i dziedzictwem narodowym w społeczeństwie. Tu też w zdecydowanej większości NGO nie zatrudniają pracowników w oparciu o umowy o pracę, ze względu na wysokie koszty utrzymania pracownika na stanowisku. Wynika to niewątpliwie z faktu, że finanse są najsłabszą stroną wszystkich analizowanych organizacji.

Tabela 1. Zestawienie otwartych konkursów ofert ogłoszonych przez Samorząd Województwa Kujawsko-Pomorskiego w latach 2011-2012.

\begin{tabular}{|r|l|c|c|}
\hline \multirow{2}{*}{ Lp. } & \multicolumn{1}{|c|}{ Nazwa projektu } & \multicolumn{2}{c|}{$\begin{array}{c}\text { Przyznane środki } \\
\text { w PLN }\end{array}$} \\
\cline { 3 - 4 } & & 2011 & 2012 \\
\hline 1. & $\begin{array}{l}\text { Upowszechnianie i rozwój kultury, sztuki, ochrona } \\
\text { tradycji i dziedzictwa narodowego }\end{array}$ & 1008000 & 968985 \\
\hline 2. & Upowszechnianie i rozwój kultury fizycznej & 517200 & 537500 \\
\hline
\end{tabular}


Wybrane aspekty współpracy samorzq̨du terytorialnego...

\begin{tabular}{|c|c|c|c|}
\hline 3. & $\begin{array}{l}\text { Rozwiązywanie problemów alkoholowych w woje- } \\
\text { wództwie kujawsko-pomorskim }\end{array}$ & 200000 & 180000 \\
\hline 4. & $\begin{array}{l}\text { Przeciwdziałanie narkomanii w województwie kujaw- } \\
\text { sko-pomorskim }\end{array}$ & 250000 & 225000 \\
\hline 5. & $\begin{array}{l}\text { Aktywizacja środowisk wiejskich w zakresie rozwią- } \\
\text { zywania problemów alkoholowych, narkomanii } \\
\text { i innych uzależnień }\end{array}$ & 50000 & 50000 \\
\hline 6. & $\begin{array}{l}\text { Wspieranie zajęć rozwojowych dla dzieci i młodzieży } \\
\text { zagrożonych wykluczeniem społecznym }\end{array}$ & 250000 & 270000 \\
\hline 7. & $\begin{array}{l}\text { Wspieranie pracy wychowawczej z dziećmi i młodzie- } \\
\text { żą realizowanej przez organizacje młodzieżowe }\end{array}$ & 450000 & 360000 \\
\hline 8. & $\begin{array}{l}\text { Wspieranie aktywności i integracji społecznej senio- } \\
\text { rów }\end{array}$ & 90000 & 90000 \\
\hline 9. & $\begin{array}{l}\text { Wsparcie działań z zakresu opieki nad osobami prze- } \\
\text { wlekle chorymi }\end{array}$ & 270000 & 270000 \\
\hline 10. & Ochrona i promocja zdrowia & 100000 & 60000 \\
\hline 11. & Upowszechnianie turystyki i krajoznawstwa & 150000 & 120000 \\
\hline 12. & Rehabilitacja dzieci niewidomych i słabowidzących & 100000 & - \\
\hline 13. & $\begin{array}{l}\text { Dofinansowanie wkładu własnego do projektów finan- } \\
\text { sowanych z funduszy zewnętrznych }\end{array}$ & 66700 & 69200 \\
\hline 14. & $\begin{array}{l}\text { „Forum Organizacji Pozarządowych Województwa } \\
\text { Kujawsko-Pomorskiego” }\end{array}$ & 30000 & 30000 \\
\hline 15. & $\begin{array}{l}\text { Rehabilitacja zawodowa i społeczna osób niepełno- } \\
\text { sprawnych }\end{array}$ & 191000 & 169860 \\
\hline 16. & Upowszechnianie kultury fizycznej i sportu & 1282800 & 1262170 \\
\hline 17. & $\begin{array}{l}\text { Świadczenie usług indywidualnych i grupowych } \\
\text { w języku migowym dla osób niesłyszących powyżej } \\
\text { 16. roku życia }\end{array}$ & 150000 & - \\
\hline 18. & $\begin{array}{l}\text { Wspieranie działań z zakresu opieki adopcyjno- } \\
\text {-wychowawczej }\end{array}$ & - & 133700 \\
\hline 19. & Ochrona zdrowia psychicznego & - & 40000 \\
\hline 20. & $\begin{array}{l}\text { Rehabilitacja zawodowa i społeczna osób niepełno- } \\
\text { sprawnych }\end{array}$ & - & 70140 \\
\hline
\end{tabular}

Źródło: opracowanie własne na podstawie sprawozdań z realizacji Programu współpracy Samorządu Województwa Kujawsko-Pomorskiego z organizacjami pozarządowymi i innymi podmiotami prowadzącymi działalność pożytku publicznego za 2011 i 2012 r. 
W 2012 r. w badanym województwie po raz pierwszy ogłoszony został odrębny konkurs na zadania z zakresu promocji zdrowia psychicznego oraz konkurs dotyczący opieki adopcyjno-wychowawczej. Jest to po części efekt współpracy z Radą Działalności Pożytku Publicznego Województwa Kujawsko-Pomorskiego, która została powołana w lipcu 2011 r. na mocy zarządzenia Marszałka Województwa Kujawsko-Pomorskiego. Pełni ona rolę organu konsultacyjnego i opiniodawczego. W skład Rady wchodzi 14 osób, w tym 7 osób reprezentujących organizacje pozarządowe, 1 osoba reprezentująca wojewodę, 2 radnych wojewódzkich i 4 pracowników Urzędu Marszałkowskiego.

Tabela 2. Zestawienie przyznanych środków w formie dotacji na realizację zadań zleconych w trybie konkursów otwartych oraz trybie pozakonkursowym w latach 2011-2012.

\begin{tabular}{|c|c|c|c|}
\hline Rok & $\begin{array}{c}\text { Eączna wysokość } \\
\text { przyznanych dotacji } \\
\text { w PLN }\end{array}$ & $\begin{array}{c}\text { Liczba organizacji pozarzą- } \\
\text { dowych realizujących } \\
\text { zadania }\end{array}$ & $\begin{array}{c}\text { Liczba zrealizowa- } \\
\text { nych projektów }\end{array}$ \\
\hline 2011 & 5349503 & 542 & 585 \\
\hline 2012 & 5289659 & 521 & 549 \\
\hline
\end{tabular}

Źródło: opracowanie własne na podstawie sprawozdania z realizacji Programu współpracy Samorządu Województwa Kujawsko-Pomorskiego z organizacjami pozarządowymi i innymi podmiotami prowadzącymi działalność pożytku publicznego za 2011 i 2012 r.

Finansowa współpraca między Samorządem Województwa Kujawsko-Pomorskiego i organizacjami pozarządowymi opierała się na zlecaniu realizacji zadań publicznych wraz z całościowym lub też częściowym wsparciem finansowym. Zlecanie zadań odbywało się w drodze otwartych konkursów ofert. W 2011 r. ogłoszono 17 konkursów ofert, natomiast w 2012 r. - 19. Ponadto zadania zlecano także z pominięciem otwartego konkursu ofert $\mathrm{w}$ tzw. trybie pozakonkursowym. Zestawienie dotacji w obu trybach przedstawia Tabela 2. W latach 2011 i 2012 zauważalny jest nieznaczny spadek przyznanych dotacji oraz liczby organizacji pozarządowych i ilości zrealizowanych przez nie projektów. Jest to efekt nikłego zainteresowania kilkoma konkursami, które samorząd zmuszony był 
unieważnić. Aby wykluczyć taką sytuację w przyszłości, Biuro Współpracy z Organizacjami Pozarządowymi działające przy Urzędzie Marszałkowskim oferuje stałe wsparcie merytoryczne oraz bezpłatne doradztwo w zakresie prawa i rachunkowości. Dodatkowo systematycznie przeprowadza szkolenia na temat zasad przygotowywania ofert konkursowych. W 2013 r. samorząd województwa zaplanował: dalsze udoskonalenie procedur konkursowych, zwiększony dostęp do informacji oraz pogłębioną analizę kondycji trzeciego sektora w województwie w oparciu o przeprowadzone badania. W ten sposób samorząd stara się zachęcić organizacje non profit do aktywnego uczestnictwa w przejmowaniu zadań publicznych i działań na rzecz lokalnego społeczeństwa. Kierunek takich działań jest właściwy, gdyż administracja samorządowa odgrywa istotną rolę w zakresie pobudzania aktywności organizacji i wspierania ich inicjatyw. Rzeczywiste zainteresowanie problemami i propozycjami NGO oraz udzielanie pomocy, oczywiście w miarę możliwości finansowych samorządu, stanowi akcelerator rozwoju trzeciego sektora. Współpracę samorządu z NGO ma ułatwiać pełnomocnik do spraw organizacji samorządowych. Utrudniają ją występujące niekiedy nieporozumienia i niewystarczająca wiedza urzędników o zasadach funkcjonowania organizacji pozarządowych.

Należy jeszcze zauważyć, że relacje pomiędzy organizacjami pozarządowymi a samorządami mają charakter zarówno formalny (udział w konkursach, podania, oficjalne pisma), jak i nieformalny (osobiste kontakty, znajomości itp.). Z doświadczeń współdziałania samorządu z NGO w badanym województwie wynika, że jeśli w ramach działań formalnych nie udaje się uzyskać wsparcia, wykorzystuje się niejednokrotnie relacje nieformalne, ponieważ jest to w wielu przypadkach skuteczniejsze. Należy przy tym pamiętać, że mechanizm ten może przyczyniać się z jednej strony do powstawania patologii społecznych, a z drugiej do budowy kapitału społecznego - urzędnicy administracji samorządowej zlecają projekt tym, do których mają osobiste zaufanie. Organizacje pozarządowe chętnie opierają współpracę z samorządem na nieformalnych kontaktach. 
Taka współpraca pozwala NGO poczuć się docenionym i buduje kapitał społeczny ${ }^{17}$.

Sytuacja finansowa organizacji pozarządowych z terenu województwa kujawsko-pomorskiego jest zbliżona do sytuacji w Polsce, pod względem zarówno wysokości przychodów, jak i źródła ich pochodzenia. Najważniejszym źródłem przychodów NGO w analizowanym województwie są dotacje samorządów gmin. Dla przykładu: w 2012 r. w Toruniu zrealizowano 422 projekty na łączną kwotę 11,3 mln zł. Wysokość dotacji gminy, w zależności od rodzaju zadania wynosiła od 50 do 80\% kosztów jego realizacji ${ }^{18}$. Taki stan rzeczy świadczy o tym, że aktywność trzeciego sektora koncentruje się na najbliższym otoczeniu, a samorząd lokalny jest najbardziej oczywistym partnerem w zakresie współpracy finansowej. Traktowanie jednak dotacji z samorządu gminy jako głównego źródła finansowania dla NGO ma też negatywne strony. Niekiedy oznacza nieumiejętność skutecznego aplikowania o fundusze spoza samorządu, o czym świadczy względnie niski odsetek organizacji, które korzystają ze środków unijnych. To z kolei przekłada się na słabą dynamikę rozwoju organizacji. Można byłoby zatem sugerować, aby zarówno samorząd województwa, jak i samorządy lokalne w ścisłej współpracy z wyspecjalizowanymi organizacjami pozarządowymi podejmowały inicjatywy o charakterze szkoleniowo-doradczym, które wpłyną na skuteczność pozyskiwania środków finansowych z różnych źródeł.

\section{Zakończenie}

Powstanie trzeciego sektora należy traktować jako wypełnienie luki pomiędzy sektorem prywatnym i publicznym. Organizacje pozarządowe

17 Obserwacje te są potwierdzone badaniami ogólnopolskimi. Zob. np. Raport z badań: Współpraca pożytku administracji publicznej i organizacji pozarzqdowych. Monitoring funkcjonowania ustawy o działalności publicznego i o wolontariacie, Instytut Spraw Publicznych, Warszawa 2007, s. 11-12.

18 Zob. więcej M. Flisykowska-Kacprowicz, Dotacje z budżetu samorzq̨du dla organizacji pozarzq̨dowych prowadzqcych działalność pożytku publicznego w praktyce miasta Torunia, [w:] A. Borodo (red.), Dotacje i subwencje w systemie finansowym samorzqdu terytorialnego, Toruń 2013, s. 311-312. 
współpracują z samorządem ze względu na wspólny przedmiot działań, wspólne cele i możliwość połączenia wysiłków oraz z uwagi na pozostające w gestii jednostek samorządowych środki publiczne, które w ramach zlecania zadań mogą one przekazywać organizacjom. Wielkość tych środków jest wskaźnikiem intensywności kontaktów, a ich wyraźny wzrost wskazuje na zacieśnianie współpracy między samorządem a organizacjami samorządowymi. Skuteczność działań podejmowanych przez organizacje trzeciego sektora sprawia, że rośnie ich rola w kreowaniu pozytywnych zmian w środowisku lokalnym, co ma również wpływ na rozwój regionu. Szczególnie ważne staje się wykorzystanie zasobów tych organizacji, a zwłaszcza zasobów wiedzy, dzięki którym możliwa staje się kompleksowa identyfikacja potrzeb i problemów mieszkańców na danym terenie. Rola sektora pozarządowego jako partnera samorządu województwa umożliwia więc skuteczną realizację wspólnego, długofalowego celu, jakim jest rozwój społeczeństwa obywatelskiego oraz zwiększenie stopnia zaspokojenia potrzeb ludności.

Partycypację ludności w realizacji polityki społecznej samorządu reguluje szereg przepisów prawnych. W praktyce jednak procedury tworzenia i wdrażania działań społecznych stosowane przez samorządy są bardzo zróżnicowane, wynikają bowiem z dość dużej swobody ich kształtowania. Jest to związane ze specyfiką określonych regionów oraz charakterystycznych dla danego miejsca potrzeb i warunków działania.

W województwie kujawsko-pomorskim samorząd podjął decyzję o sformułowaniu planu wieloletniej współpracy z organizacjami pozarządowymi na lata 2011-2015. Jest to działanie fakultatywne, które ułatwia konstruowanie planów rocznych współpracy. Co najważniejsze, plan ten stwarza warunki realizacji wielu inicjatyw mieszkańców regionu oraz pomaga w budowaniu dialogu obywatelskiego. Z przeprowadzonej analizy wynika, że obie strony mają atuty, które można wykorzystać w rozwiązywaniu lokalnych problemów społecznych. Ułomnością tej współpracy bywa niekiedy paternalizm administracji samorządu wobec instytucji, w których dużą część działaczy stanowią wolontariusze bez profesjonalnego przygotowania. 


\section{Bibliografia:}

Czaja-Hliniak I., Prawnofinansowe aspekty współpracy jednostek samorzqdu terytorialnego z organizacjami pozarzq̨dowymi $w$ realizacji zadań publicznych na przykładzie gminy - miasta metropolitalnego, [w:] J. Gliniecka, E. Juchniewicz, T. Sowiński, M. Wróblewska (red.), Prawo finansowe samorzqdu terytorialnego. Prawo finansowe wobec wyzwań XXI wieku, Wydawnictwa Fachowe CeDeWu, Gdańsk-Nynäshamn-Sztokholm 2013.

Gliński P., B. Lewenstein, A. Siciński, Samoorganizacja społeczeństwa polskiego: trzeci sektor, Wydawnictwo Instytutu Filozofii i Socjologii PAN, Warszawa 2002.

Grzelońska U., Rola sektora non profit w polskiej gospodarce, „Studia Ekonomiczne” 2011, nr 4 (LXXI), Instytut Nauk Ekonomicznych PAN.

Flisykowska-Kacprowicz M. Dotacje z budżetu samorzqdu dla organizacji pozarzq̨dowych prowadzqcych działalność pożytku publicznego w praktyce miasta Torunia, [w:] A. Borodo (red.), Dotacje i subwencje w systemie finansowym samorzqdu terytorialnego, TNOiK, Toruń 2013.

Ofiarska M., Zasady zlecania organizacjom pozarzq̨dowym wykonania zadań gminy, „Annales Universitatis Mariae Curie-Skłodowska”, Sectio H Oeconomia, vol. XLVI, 3, Lublin 2012.

Ofiarski Z., Finansowanie zadań zleconych przez gminę organizacjom pozarzqdowym, „Annales Universitatis Mariae Curie-Skłodowska”, Sectio H Oeconomia, vol. XLVI, 3, Lublin 2012.

Schmidt J., Rozwój organizacji pozarzq̨dowych. Teoria i praktyka, Wydawnictwo Naukowe Sedno, Warszawa 2012.

Seibel W., H.K. Anheier, Sociological and political science approaches to the third sector, [w:] H.K. Anheier, W. Seibel (red.), The Third Sector: Comparative Studies of Nonprofit Organisations, Walter de Gruyter, Berlin-New York, 1990. 